\title{
Hubungan Pengetahuan Ibu Dengan Kunjungan Balita ke Posyandu Beringin Kencana Tabunganen Kabupaten Barito Kuala
}

\author{
Relation of Mothers Knowledge With the Visit of Balita to Posyandu Beringin Kencana \\ Tabunganen Barito Kuala District
}

\author{
Irma Wulandari ${ }^{\star *}$, Lily Citra ${ }^{2}$ \\ ${ }^{1}$ Akper Pandan Harum Banjarmasin, JI.Veteran KM 5,5 Gg.GT Seman no 79, Sungai Lulut \\ Banjarmasin \\ ${ }^{2}$ Alumni Akper Pandan Harum Banjarmasin JI.Veteran KM 5,5 Gg.GT Seman no 79, Sungai \\ Lulut Banjarmasin \\ *korespondensi: wulandari.irma79@gmail.com
}

\begin{abstract}
The posyandu program was carried out for the benefit of the community, in Indonesia in 2010 toddler visits to the posyandu were still 50\%. This study aims to determine the relationship of knowledge of mothers of children under five with toddlers visits to posyandu in Beringin Kencana village, Tabunganen District, Barito Kuala Regency The study is analytical, a type of correlational research with a cross-sectional approach. The population and sample were all mothers who had children under five in Beringin Kencana Village, Tabunganen District, Barito Kuala Regency, which amounted to 72 people. The sampling technique used is total sampling. The data collection instrument uses a questionnaire and observation sheet. The statistical test used was the Chi-Square test. The results of the study were 72 respondents, more than $50 \%$ were less knowledgeable (69.5\%), knowledgeable (5.5\%), knowledgeable enough (25\%) about posyandu knowledge, more than $50 \%$ of respondents $(52.8 \%)$ regularly visit toddlers posyandu. The results of the analysis using the chi square test showed $p$ value: 0.516 , the value of $p>0.05$, there was no relationship between maternal knowledge of children under five and toddler visits to the posyandu. Based on the results of the study, it is recommended that the Tabunganen Health Center improve information provision by distributing leaflets on the benefits of toddlers posyandu and toddler visits to the posyandu as well as empowering the community by involving the community to become health cadres. To the next researchers are expected to be able to conduct research with different variables.
\end{abstract}

Keywords : Knowledge, Visits, Posyandu

\section{Pendahuluan}

Posyandu merupakan bentuk peran serta masyarakat di bidang kesehatan yang dikelola oleh kader dengan sasaran seluruh anggota masyarakat. Posyandu mempunyai tujuan memelihara dan meningkatkan kesehatan ibu, bayi balita dan pasangan usia subur. Kegiatan diposyandu merupakan kegiatan nyata yang melibatkan partisipasi masyarakat dalam upaya pelayanan kesehatan dari masyarakat dan oleh masyarakat yang telah mendapatkan pendidikan dan pelatihan dari pukesmas mengenai pelayanan kesehatan dasar. Kelangsungan posyandu tergantung dari partisipasi masyarakat itu sendiri.
Rendahnya peran serta masyarakat dalam kegiatan posyandu disebabkan adanya beberapa faktor. Faktor tersebut antara lain, umur balita, jumlah anak, jarak rumah ke posyandu terlalu jauh, kurangnya menarik sarana prasarana di posyandu, dan kurangnya pengetahuan ibu tentang pentingnya berkunjung ke posyandu (8). Data Riset Kesehatan Dasar (Riskesdas) tahun 2013, Frekuensi penimbangan $>4$ kali sedikit menurun pada tahun 2013 (44,6\%) daripada tahun 2007 $(45,4 \%)$. Pada anak umur 6-59 bulan yang tidak pernah ditimbang dalam enam bulan terakhir meningkat dari $25,5 \%$ di tahun 2007, menjadi 34,3\% pada tahun 2013. 
Sebaiknya semakin tinggi umur anak semakin tinggi pula presentase anak yang tidak pernah ditimbang di Posyandu. Pada anak sampai usia lima tahun seharusnya dibawa ke Posyandu setiap bulan. Data Riset Kesehatan Dasar (Riskesdas) Provinsi Kalimantan Selatan tahun 2010 persentase penimbangan enam bulan terakhir anak umur 6-59 bulan di Provinsi Kalimantan Selatan yang tertinggi adalah sebanyak 1-3 kali (38,5\%). Tetapi persentase anak 6-59 bulan yang tidak pernah di timbang selama enam bulan terakhir di Provinsi Kalimantan Selatan cukup banyak, yaitu $26,4 \%$ tertinggi di Tanah Bumbu (4). Data dari Dinas Kesehatan Batola semua Puskesmas yang ada di Barito Kuala cakupan balita yang di timbang paling tinggi adalah Puskesmas Berangas sebesar $98,6 \%$ dan terendah Puskesmas Jelapat 50,1\%. Data dari Puskesmas Tabunganen cakupan balita yang di timbang adalah $53,7 \%$ (7). Data dari Puskesmas Tabunganen jumlah seluruh bayi dan balita yang ada di Desa Beringin Kencana Kecamatan Tabunganen berjumlah 88 orang terdiri dari 16 orang bayi dan 72 orang balita. Berdasarkan studi pendahuluan pada 7 orang ibu balita, 4 orang mengatakan kurang memahami tentang posyandu. Data kunjungan balita 3 bulan terakhir di Posyandu Desa Beringin Kencana yaitu pada bulan Agustus 2017 sekitar $10,08 \%$ balita yang tidak datang ke posyandu, pada bulan September 2017 sekitar 9,36\%balita yang tidak datang ke posyandu, dan pada bulan Oktober sekitar $10,8 \%$ balita yang tidak datang ke posyandu.

Tujuan penelitian ini adalah untuk mengetahui hubungan pengetahuan ibu balita dengan kunjungan balita ke posyandu di desa Beringin Kencana Kecamatan Tabunganen. Kabupaten Barito Kuala.

\section{Metode Penelitian}

Penelitian ini bersifat analitik dengan dengan pendekatan cross-sectional yaitu suatu rancangan penelitian yang mempelajari dinamika korelasi antara sebab dengan akibat pada saat yang bersamaan.
Populasi dan sampel pada penelitian ini adalah seluruh ibu yang mempunyai anak balita di Desa Beringin Kencana Kecamatan Tabunganen Kabupaten Barito Kuala yang berjumlah 72 orang. Tehnik pengambilan sampel yang digunakan adalah total sampel (9), dimana total populasi dijadikan sampel. Instrumen penelitian yang digunakan kuesioner yang berisi tentang pengetahuan ibu balita tentang posyandu dan lembar kunjungan balita ke posyandu dalam 1 tahun. Analisa data dilakukan dengan analisa Univariat dengan tabel distribusi frekuensi dan bivariat dengan menggunakan uji statistic chi-square.

\section{Hasil Penelitian \\ Analisis Univariat}

1. Pengetahuan Ibu Balita

Tabel 1.1 Distribusi Frekuensi Pengetahuan Ibu Balita tentang posyandu di Desa Beringin Kencana Kecamatan Tabunganen

\begin{tabular}{c|c|c}
\hline Pengetahuan & Frekuensi & $\begin{array}{c}\text { Persentase } \\
\text { (\%) }\end{array}$ \\
\hline Baik & 4 & 5,5 \\
Cukup & 18 & 25 \\
Kurang & 50 & 69,5 \\
\hline Total & 72 & 100 \\
\hline
\end{tabular}

Berdasarkan tabel diatas menunjukkan bahwa dari 72 responden, 50 responden $(69,5 \%)$ memiliki pengetahuan kurang tentang posyandu

2. Kunjungan Balita

Tabel 1.2 Distribusi Frekuensi Kunjungan Balita ke posyandu di Desa Beringin Kencana Kecamatan Tabunganen

\begin{tabular}{c|c|c}
\hline Kunjungan & Frekuensi & Persentase(\%) \\
\hline Teratur & 38 & 52,8 \\
TidakTeratur & 34 & 47,2 \\
& & \\
\hline Total & 72 & 100 \\
\hline
\end{tabular}

Berdasarkan tabel 1.2 menunjukkan bahwa dari 72 responden, 34 responden $(47,2 \%)$ tidak teratur mengunjungi posyandu. 


\section{Analisis Bivariat}

3. Hubungan antara pengetahuan ibu balita dengan kunjungan balita ke posyandu di desa Beringin Kencana Kecamatan Tabunganen

Tabel 1.3 Tabulasi silang tingkat pengetahuan hubungan antara pengetahuan ibu balita dengan kunjungan balita ke posyandu di desa Beringin Kencana Kecamatan Tabunganen

\begin{tabular}{|c|c|c|c|c|c|c|}
\hline \multirow{3}{*}{$\begin{array}{l}\text { Peng } \\
\text { etah } \\
\text { uan }\end{array}$} & \multicolumn{4}{|c|}{ Kunjungan Balita } & \multirow{2}{*}{\multicolumn{2}{|c|}{ Total }} \\
\hline & \multicolumn{2}{|c|}{$\begin{array}{l}\text { Tidak } \\
\text { Teratur }\end{array}$} & \multicolumn{2}{|c|}{ Teratur } & & \\
\hline & $\mathbf{N}$ & $\%$ & $\mathbf{N}$ & $\%$ & $\mathbf{N}$ & $\%$ \\
\hline $\begin{array}{c}\text { Kura } \\
n g\end{array}$ & 23 & 31,9 & 27 & 37,5 & 50 & 100 \\
\hline $\begin{array}{c}\text { Cuku } \\
\mathrm{p}\end{array}$ & 8 & 11,1 & 10 & 13,9 & 18 & 100 \\
\hline Baik & 3 & 4,2 & 1 & 1,4 & 4 & 100 \\
\hline \multicolumn{7}{|c|}{$P$ value : 0,516} \\
\hline
\end{tabular}

Berdasarkan tabel 1.3 menunjukkan bahwa dari 72 responden, 18 responden yang berpengetahuan cukup maupun 50 responden yang berpengetahuan kurang tentang posyandu cenderung teratur membawa balitanya ke posyandu. Berdasarkan hasil analisa dengan menggunakan uji chi square menunjukkan hasil yang diperoleh ( $p$ value) 0,516 . Karena nilai $p>0,05$ maka Ho diterima sehingga dapat diambil kesimpulan bahwa tidak ada hubungan antara pengetahuan ibu balita dengan kunjungan balita ke posyandu di desa Beringin Kencana Kecamatan Tabunganen,Kabupaten Barito Kuala.

\section{Pembahasan}

Berdasarkan hasil penelitian pada tabel 1.1 menunjukkan bahwa dari 72 responden, 50 responden $(69,5 \%)$ memiliki pengetahuan kurang tentang posyandu. Hasil kuesioner menunjukkan bahwa responden kurang mengetahui tentang maksud posyandu balita, tujuan dari posyandu, manfaat posyandu bagi balita. Hal ini di sebabkan karena sebagian besar penduduk di Desa Beringin Kencana Kecamatan Tabunganen berpendidikan SD, menurut Nursalam (14) semakin rendah pendidikan seseorang maka akan semakin kurang pengetahuannya. Meskipun sekarang ini dengan adanya kemajuan jaman informasi dapat diperoleh dari media massa berupa media elektronik dan media cetak yang memberikan informasi tentang manfaat mengunjungi posyandu.

Berdasar hasil penelitian pada tabel 1.2 menunjukkan bahwa dari 72 responden, 34 responden $(47,2 \%)$ tidak teratur mengunjungi posyandu. Ketidakteraturan kunjungan ke posyandu disebabkan kurangnya pengetahuan ibu tentang posyandu balita, hasil penelitian menunjukkan bahwa $69,5 \%$ responden memiliki pengetahuan kurang tentang posyandu balita. Berdasarkan penelitian Rahmadinliyani dan Meililiyanie (8) menunjukkan bahwa beberapa faktor lain yang mempengaruhi ketidakaktifan ibu dalam mengunjungi posyandu adalah motivasi ibu, sosial budaya ibu, dukungan dari masyarakat, peran petugas dan kader serta kebijakan pemerintah.

Berdasar hasil penelitian pada tabel 1.3 menunjukkan bahwa dari 72 responden, 18 responden yang berpengetahuan cukup maupun 50 responden yang berpengetahuan kurang tentang posyandu cenderung teratur membawa balitanya ke posyandu. Berdasarkan hasil analisa dengan menggunakan uji chi square menunjukkan hasil yang diperoleh ( $p$ value) 0,516 . Karena nilai $p>0,05$ maka Ho diterima sehingga dapat diambil kesimpulan bahwa tidak ada hubungan antara pengetahuan ibu balita dengan kunjungan balita ke posyandu di desa Beringin Kencana Kecamatan Tabunganen, Kabupaten Barito Kuala. Hasil penelitian ini tidak sesuai dengan penelitan yang dilakukan oleh Mudawamah, (12), menunjukkan bahwa ada hubungan pengetahuan ibu tentang posyandu dengan keaktifan ibu dalam kegiatan posyandu di Desa Simo Kecamatan Kradenan Kabupaten Grobogan. Hasil penelitian ini sesuai dengan hasil penelitan Fitriani (8) yang menyatakan bahwa tidak ada hubungan yang bermakna antara pengetahuan ibu dengan kunjungan ke posyandu di wilayah kerja puskesmas 
Segayam. Ibu balita dengan pengetahuan cukup dan kurang namun mempunyai kunjungan ke posyandu yang teratur dapat dikaitkan dengan faktor yang dapat membentuk perilaku tanpa dilandasi pengetahuan terlebih dahulu antara lain motivasi ibu, jarak tempat tinggal, serta dukungan keluarga. Selain itu jarak tempat tinggal yang dekat dengan kegiatan posyandu, dapat memudahkan ibu untuk berkunjung ke posyandu. Adanya dukungan keluarga dapat memotivasi ibu untuk secara rutin ke posyandu.

\section{Kesimpulan}

Kesimpulan penelitian ini adalah:

1. $69,5 \%$ responden memiliki pengetahuan kurang terhadap posyandu balita.

2. $47,2 \%$ responden tidak teratur mengunjungi posyandu balita.

3. Tidak ada hubungan antara Pengetahuan lbu Balita dengan Kunjungan Balita Ke Posyandu Desa Beringin Kencana Kecamatan Tabunganen

\section{Daftar Pustaka}

1. Arikunto. Prosedur Penelitian Suatu Pendekatan Praktik. Jakarta: PT Rineka Cipta; 2006

2. Bejo Siswanto. Manajemen Tenaga Kerja Rancangan dalam Pendayagunaan dan Pengembangan Unsur Tenaga Kerja. Bandung: Sinar Baru; 2010

3. Badan penelitian dan pengembangan kesehatan, Riset Kesehatan Dasar (Riskesda 2013), Kementrian Kesehatan Republik Indonesia , Jakarta ; 2013

4. Badan penelitian dan pengembangan kesehatan, Riset Kesehatan Dasar (Riskesda 2010), Kementrian Kesehatan Republik Indonesia , Kalimantan Selatan; 2010

5. Depkes RI. Pedoman umum pengelolaan posyandu Jakarta:Depkes $\mathrm{RI} ; 2006$
6. Dinas Kesehatan Provinsi Jawa Tengah.Kunjungan Balita ke Posyandu Jateng: Dinkes; 2007

7. Dinas Kesehatan Kabupaten Barito Kuala. Laporan tahunan data jumlahkunjunganbalitakeposyandu .BATOLA.Dinas kesehatan; 2016

8. Fitriani, Idil. Hubungan Pendidikan ibu Dengan Kunjungan Balita ke Posyandu di Kecamatan Pemulutan Selatan Kabupaten Ogan Ilir . Jurnal ILmiah. III (2) ; 2010

9. Hidayat .Aziz Alimul. Metode Penelitian Keperawatandan Teknik Analisis Hidayat, Data.Jakarta :Salemba Medika; 2007

10. Machfoedz, Mahmud. Statistika Deskriptif. Yogyakarta: Fitramaya (2010)

11. Mitayani ,. Buku Saku IImu Gizi. Jakarta : Trans Info Media (TIM); 2010

12. Mudawamah, Hanik. Hubungan antara pengetahuan tentang posyandu dengan keaktifaan ibu dalam kegiatan posyandu di Desa Simo Kecamatan Kradenan Kabupaten Grobogan. Skripsi. Universitas Muhammadiyah Surakarta ; 2017

13. Nursalam. Konsep dan Penerapan Metodologi Penelitian IImu Keperawatan PedomanSkripsi, Tesis dan Instrumen Penelitian Keperawatan, Jakarta: Salemba Medika; 2003

14. Nursalam . Konsep dan Penerapan Metodologi Penelitian Keperawatan; 2013

15. Notoatmodjo, Soekidjo. Pendidikandan Perilaku Kesehatan. Jakarta: Rineka Cipta; 2003

16. Notoatmodjo, Soekidjo. Promosi Kesehatan Teori dan Aplikasi, Jakarta: Rineka Cipta; 2005

17. Notoatmodjo, Soekidjo. Metodologi penelitian kesehatan. Jakarta: PT. Rineka Cipta; 2010

18. Runjati. Asuhan Kebidanan Komunitas, Jakarta:EGC; 2010

19. Sutomo, B. Makanan Sehat Pendamping ASI. Demedia. Jakarta; 2010 
20. Waluyo, L,. Mikrobiologi Umum. UPT Penerbit UMM. Malang; 2007

21. Wawan A \& Dewi M. Teori \& Pengukuran Sikap dan Perilaku Manusia,Yogyakarta .Nuha Medika; 2010

22. Yuni, Oktami. Panduan Lengkap Posyandu untuk Bidan dan Kader. Yogyakarta : Nuha medika; 2014

23. Dr-suparyanto. konsep balita; 2011. [Cited 5 November 2017]. Available from:

http://drsuparyanto.blogspot.com/2011/ 03/konsep-balita.htm, 